\title{
Recesión de metástasis óseas diseminadas en un paciente con cáncer de próstata
}

\author{
Peyrí Rey E. \\ Urología. CAP Numancia ICS. Barcelona.
}

Actas Urol Esp. 2008;32(10):1050

$P_{p}$ aciente de 67 años que acude por un cuadro de polaquiuria acompañado de lumbalgia sacra. Tacto rectal de próstata dura fija de tamaño grande. Una analítica con un PSA de $3.453 \mathrm{ng} / \mathrm{ml}$, fosfatasa alcalinas de 423 U/L y un htco de 33. Biopsia de próstata de adenocarcinoma Gleason 4+4, afectando al 90\% de la muestra de ambos lóbulos, con invasión perineural.

Gammagrafía ósea (Fig. 1), presenta múltiples hipercaptaciones de aspecto confluyente que afectan a todo el esqueleto axial incluyendo la calota craneal y tercio proximal de fémures y que conforman un patrón de diseminación ósea medular generalizada. El TAC no evidencia adenopatías radiológicas, si infiltración local de ambas vesículas seminales.

Realizamos de inmediato un bloqueo androgénico completo, con control de PSA a los 3 meses de $0,68 \mathrm{ng} / \mathrm{ml}$ y fosfatasas alcalinas de $97 \mathrm{U} / \mathrm{L}$, testosterona $0,2 \mathrm{ng}$.

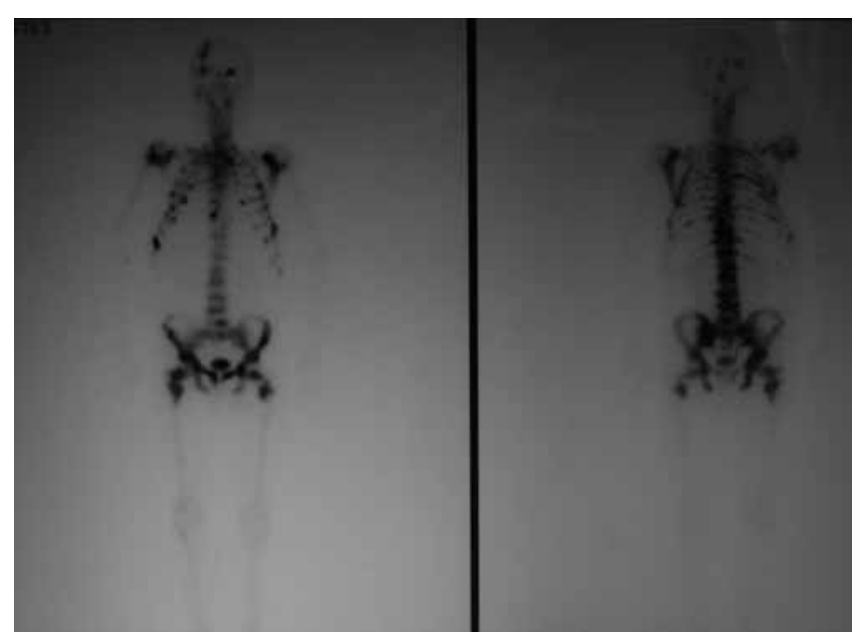

FIGURA 1
Al control anual tras el bloqueo hormonal completo, el paciente mejoro de su dolor óseo presentando un de PSA 0,12 ng/ml, fosfatasas alcalinas de $77 \mathrm{U} / \mathrm{L}$ y testosterona 0,2 ng. La gammagrafía ósea (Fig. 2), muestra una práctica desaparición de las metástasis óseas, quedando un leve refuerzo de captación del trazador en columna dorsal media, en articulación sacroilíaca izquierda y en manubrio esternal, de aspecto residual.

Correspondencia autor: Dr. E. Peyrí Rey Urología. CAP Numancia ICS. Barcelona. Numancia, 15-27 - 08029 Barcelona Tel.: 934955886 E-mail autor: 7956epr@comb.es Información artículo: Imágenes en Urología Trabajo recibido: junio 2007 Trabajo aceptado: julio 2007 